\title{
Micro-Unit per Liter
}

National Cancer Institute

\section{Source}

National Cancer Institute. Micro-Unit per Liter. NCI Thesaurus. Code C124470.

An arbitrary unit of substance content expressed in microunit(s) per liter. 